\title{
American College of Medical Genetics position statement on gene patents and accessibility of gene testing
}

The fruits of the human genome project are rapidly redefining the medical community's views of patient care and moving us from a focus on the treatment of disease to a broader perspective in which prevention and diagnosis play equally critical roles. The American College of Medical Genetics (ACMG) believes that gene testing, which is vital to all three approaches, must remain widely accessible and affordable and that the development and improvement of safe and effective genetic tests should not be hindered. The decision of the Patent and Trademark Office (PTO) to permit the patenting of naturally occurring genes and disease-causing mutations has produced numerous difficulties. While the ACMG disagrees with the PTO over this fundamental issue, we have further concerns over current patterns of enforcement of patents on genes that are important in the diagnosis, management, and risk assessment of human disease.

This statement is directed at current practices related to such enforcement. Enforcement has been affected in one or more of these ways: monopolistic licensing that limits a given genetic test to a single laboratory, royalty-based licensing agreements with exorbitant up-front fees and per-test fees, and licensing agreements that seek proportions of reimbursement from testing services. These limit the accessibility of competitively priced genetic testing services and hinder test-specific development of national programs for quality assurance. They also limit the number of knowledgeable individuals who can assist physicians, laboratory geneticists, and counselors in the diagnosis, management, and care of at-risk patients.

Further, restricting the availability of gene testing has longterm implications beyond patient care. It affects the training of the next generation of medical and laboratory geneticists, physicians, and scientists in the area enveloped by the patent or license. It also retards the usually very rapid improvement of a test that occurs through the addition of new mutations or the use of new techniques by numerous laboratories that have accumulated samples from affected individuals over many years.

Therefore, it is the ACMG's position that:

- Genes and their mutations are naturally occurring substances that should not be patented.

- Patents on genes with clinical implications must be very broadly licensed.

- Licensing agreements should not limit access through excessive royalties and other unreasonable terms.

Revised and approved by the ACMG Executive Committee on August 2, 1999.

(C)American College of Medical Genetics, 1999

AMERICAN COLLEGE OF MEDICAL GENETICS

9650 Rockville Pike

Bethesda, Maryland 20814-3998

Phone 301-530-7127

Fax 301-571-1895

This guideline is designed primarily as an educational resource for medical geneticists and other health care providers to help them provide quality medical genetic services. Adherence to this guideline does not necessarily assure a successful medical outcome. This guideline should not be considered inclusive of all proper procedures and tests or exclusive of other procedures and tests that are reasonably directed to obtaining the same results. In determining the propriety of any specific procedure or test, the geneticists should apply his or her own professional judgment to the specific clinical circumstances presented by the individual patient or specimen. It may be prudent, however, to document in the patient's record the rationale for any significant deviation from this guideline. 